\title{
LANDSCAPE CHANGES AND THE VERTEBRATE FAUNA IN SWEDEN DURING THE LAST 150 YEARS
}

\author{
by \\ KAI CURRY-LINDAHL \\ Zoological Department, Nordiska Museet and Skansen, Stockholm
}

The Swedish countryside at the beginning of the nineteenth century was still so varied and rich that there was room for both human beings and animals almost everywhere. It is true that for thousands of years man had struggled with the advancing forests. First the primaeval deciduous forest was cleared during the warm period following the last glaciation, and after the great climatic change at the close of the Swedish Bronze Age (ca 700 B.C.) the struggle was against the encroaching spruce on practically all fronts. The struggle resulted in culture steppes, pine heaths, birch groves and wooded meadows. All these types of landscape were gradually filled with the fauna adapted to them. Different types of cultivation have alternated, and as the nature has changed, the fauna has adapted itself. But up to the nineteenth century these changes were not so great that they altered the general picture of the animal world.

Imagine Sweden a century and a half agol Spruce forests dominated then as now, but they were less uniform; they had kept their individuality and character. Wooded meadows were numerous, for the regular leaf harvest that created them was of great importance in the former agrarian economy. In that way the spruce was kept at bay and the wooded meadows could develop freely, and there the farmers could collect leaves for winter fodder. The young Swedish soil was then still virgin. Thousands of lakes, marshes and fens, the inheritage of the great ice-cap, filled the countryside. Through the country ran the glittering silver bands of streams and brooks. In spring they widened and at times the water flooded the meadows. As summer approached, the low-lying alluvial fields of sedge, horsetail and rush were transformed by the sun into natural meadows, which were mown yearly to make use of everything that could serve as fodder for the livestock during the coming winter.
It was to such a countryside that the fauna was adapted. But what fauna? By and large the same as today, but quantitatively much richer. What now remains of the animal life of certain secluded woods, the few surviving glades and wooded meadows, and in water meadows and shallow lakes rich in vegetation, represents the normal fauna of Sweden yesterday. Human activities and their variations were not unexpected and abrupt in those days. Man as a biological being behaved in almost the same way as other large animals. Man's influence on the vegetation was naturally greater than that of the wild animals, but nature's circles were not disturbed to any considerable degree. The doings of animals, including man, in Scandinavia up to the opening of the nineteenth century could be automatically fitted into the natural rhythm. Everything went on calmly; the changes were not so great that nature could not immediately adapt herself to them.

With the expansion of industry, the far-reaching consequences of the reckless draining of marshes and wet ground, the shortsighted, ruthless exploitation of the rivers for hydro-electric power stations, the growing value of the coniferous forests, Swedish nature, which had been fashioned by thousands of years in a harmonious, and for most living creatures acceptable way, was transformed violently.

Let us return to the nineteenth century. A few glimpses. of the animal world of that century will show the differences between then and now. Only a century and a half ago great parts of Sweden were still wilds, where bears, wolves and lynxes roamed in the woods, where the songs of the birds rose from the green wooded meadows, where the still water of the marshes reflected the flocks of migratory birds flying over, and where there was hardly a mountain rivulet without flashing trout. 


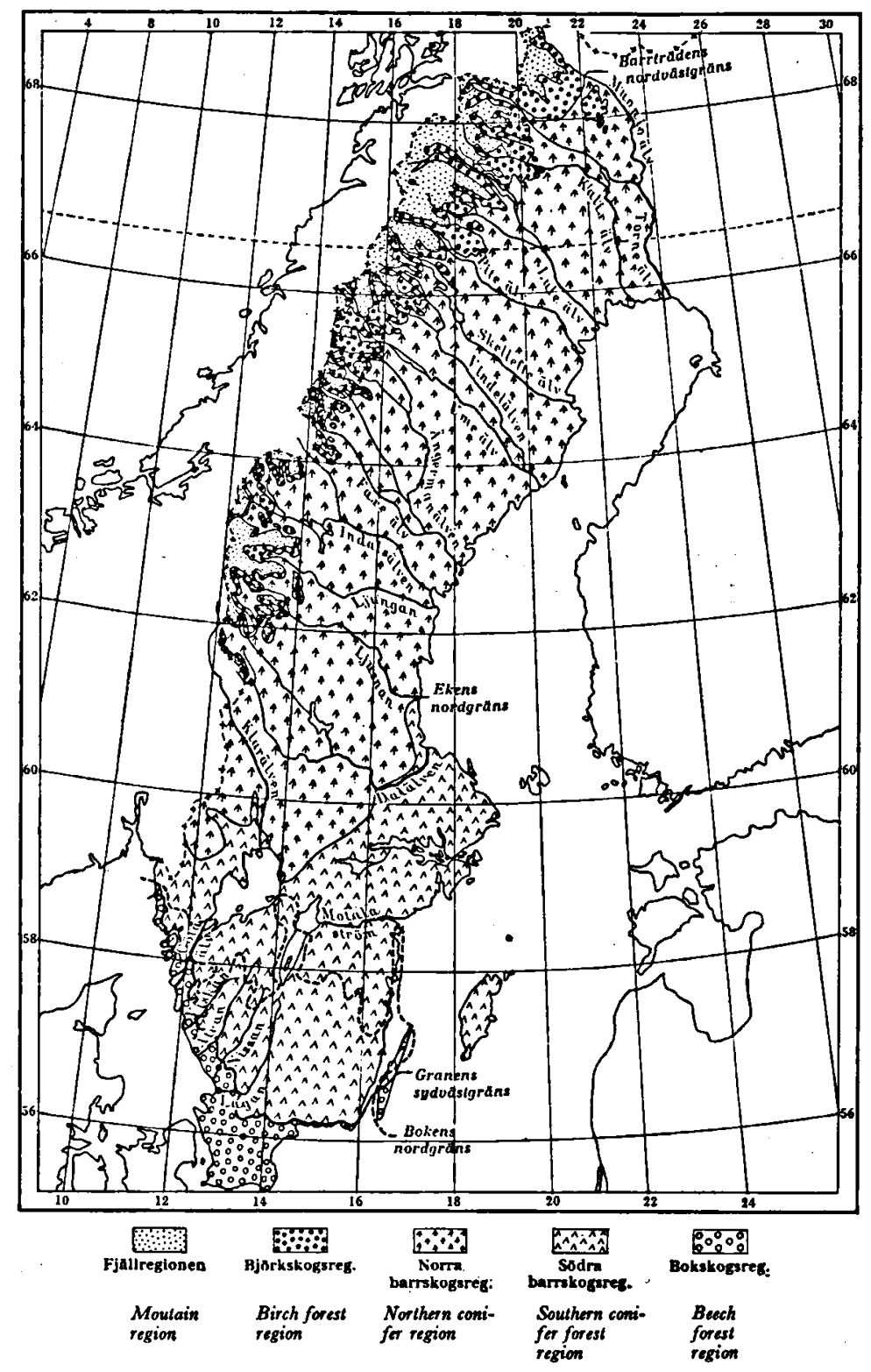

1. Vegetational map of Sweden.

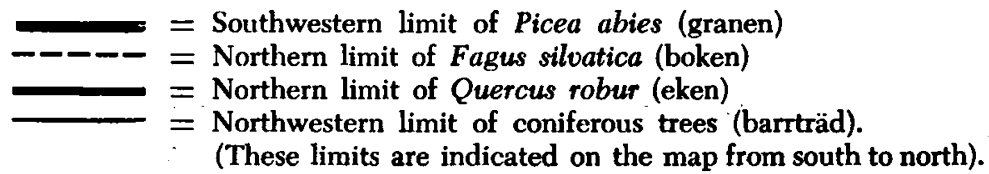

The wolf (Canis lupus), which had been retreating northwards during the eighteenth century, made a sally southwards in the nineteenth, and increased in numbers. It could still be found in the middle of the century in Scania, in southernmost Sweden, where it was even seen roving over the plains. The lynx (Lynx lynx), however, had left Scania, but was still resident and common in Blekinge and Småland. The arctic fox (Alopex lagopus) was a vagrant, and in 1832 came from the mountains right down to southernmost Sweden; nine years later the same thing happened again. This rhythm in the frequency curve of the arctic fox suggests a peak every ninth or tenth year, which is no longer observable in this now so uncommon animal. 
The most southerly haunts of the bear during the first half of the nineteenth century were in Bohuslän and Dalsland, and it was still common in Värmland and Dalarna and farther north. In Närke, Västmanland and possibly also northern Uppland, the bear (Ursus arctos) was still resident, while in Värmland the wolverine (Gulo gulo) still scampered about. In the mountains the Lapps had liquidated the last of the wild Scandinavian reindeer (Rangifer tarandus), which is nowadays to be found only in the Norwegian mountains. With that the wolf lost its most important source of winter food.

This is the background of the present situation of the carnivores in Sweden. In completely changed surroundings, or driven into a habitat less suitable for them, they are compelled to satisfy their biological requirements, of which food and shelter are the most essential.

At the beginning of the nineteenth century man

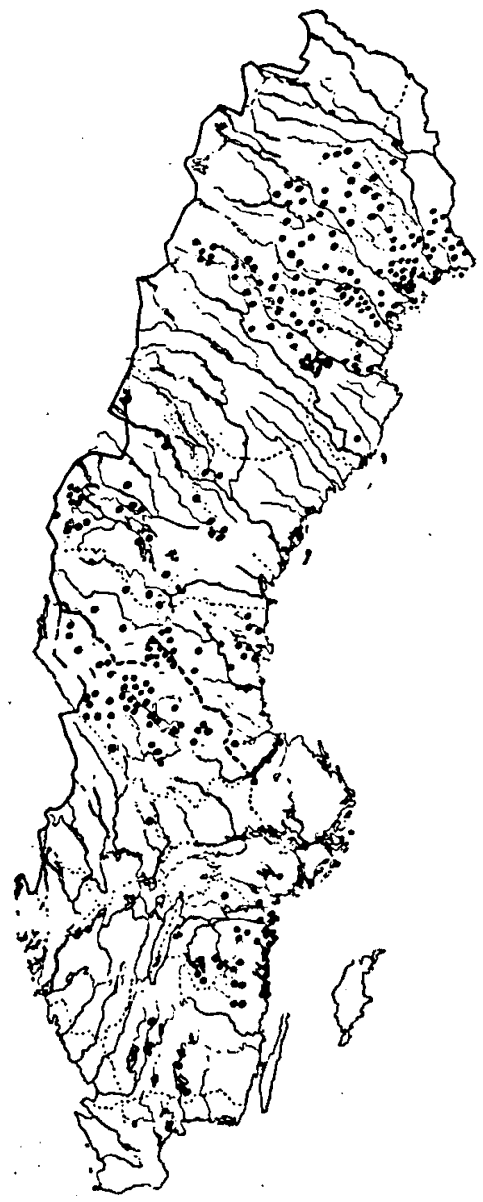

2. Map showing the distribution of the eagle owl (Bubo bubo) in Sweden 1943-1948. Each dot represents a breeding pair. After K. CuRRYLINDAHL 1950. had practically exterminated the elk (Alces alces) and roe (Capreolus capreolus) in Sweden. Wolves had done their share, of course, but their destruction of these two deer could not possibly have led to such disastrous results. It is usual nowadays to explain the rapid expansion of elks and roes as a consequence of the extermination of the wolf. Human hunters still remain, and even if they are more enlightened than they were a century ago, it can hardly be their continence with the gun or the absence of wolves that has given elks and roes increased scope in Sweden. There must be other contributory factors.

The golden oriole (Oriolus oriolus), the hoopoe (Upupa epops) and the black stork (Ciconia nigra) built their nests in the groves at Ottenby on the island of Oland in the Baltic. The roller (Coracias garrulus) flew on iridescent wings through the leafy woods of Scania. On the Scanian sand-fields round Ljungby and Ahus could be heard the mighty great bustard (Otis tarda). The hollow cry of the eagle owl (Bubo bubo) was heard all over Sweden, from Scania to Lapland. The kite (Milvus milvus) and the white-tailed sea eagle (Haliaeetus albicilla) built their nests at Lake Hornborgasjön and other places, where the great snipe (Gallinago media) was common on all wet ground round the lake. Not only at the rich bird-paradise of Hornborgasjön, which was later to be destroyed by a series of outrages and a period of culpable neglect, was this now almost extinct snipe to be found: it was also numerous in Uppland and very common in Norrland.

The voice of the bittern (Botaurus stellaris) had been silenced in the reeds, however. For some unknown reason it disappeared from Sweden as a resident bird during the nineteenth century. Perhaps exceptionally severe winters in Europe contributed towards its disappearance.

Displaying capercaillie (Tetrao urogallus) were a common sight in Swedish woods in the spring, and out on the ice and in the bogs leking black-cock (Lyrurus tetrix) bubbled their mating call. At that time the leking places attracted gallinacious birds in numbers greater than we can imagine, and still they had already begun decreasing in number. Except for small fluctuations this trend has continued.

LLEWELLYN LLOYD (1831) wrote at the beginning of the nineteenth century:

"In many woods and districts where, fifty years ago, abundance of both capercali and black game were to be found, not a bird now exists. In the spring, 
when the birds assemble for the purpose of pairing, people place themselves in ambush, and shoot without distinction cock and hens, by which means the birds are frightened and dispersed; and afterwards, when the spring is more advanced, and the young are hatched, it is certain the old hen will be sought after before they are able to fly; by one shot a whole brood of seven or eight birds are thus destroyed..."

This refers to the situation in Värmland in the years 1827-1828. Thus the decrease in game birds seems to have begun in the Värmland forests during the latter half of the eighteenth century.

During the nineteenth century it was not only the former incredibly rich population of game and forest birds that began to fail. The passing-bell tolled for many large representatives of Sweden's fauna during that century, as far as the southern part of the country was concerned. The bear and the wolf were driven northwards. The latter was also ejected from central Sweden. Owls and raptorial birds were persecuted mercilessly, with the result that many species have become very rare, or were exterminated completely in some provinces. But Sweden has not yet wholly lost a single species of owl or bird of prey which we know has bred in Sweden in historical times. Here in the north man has had such a short time at his disposal that he has luckily not been able to exterminate a single nocturnal or diurnal bird of prey. This, however, has occurred in many other European countries, where the two-legged mammals have had a few more thousand years at their disposal for their work of destruction than in Sweden.

Animals have been driven or have otherwise disappeared from Sweden in the course of centuries, but others have arrived. Human beings have introduced the fallow-deer (Dama dama), the brown hare (Lepus europaeus). the wild rabbit (Oryctolagus cuniculus), the pheasant (Phasianus colchicus), the rainbow-trout (Salmo gairdneri), and others. Many species, however, have come to Sweden of their own accord, mainly birds, naturally, for it is easier for them to occupy and colonize new domains. Many southerly sea-fishes (Zeus faber, Brama raji, Mullus surmuletus, Thunnus thynnus) also appear more frequently in Swedish waters. The harvest mouse (Micromys minutus) is waiting in Denmark for transport over the Sound, for it cannot cross under its own power. A flying mammal, the serotine bat (Eptesicus serotinus), has for the time being halted at the Danish side of the Sound, but sooner or later it will cross over and settle in Sweden. Several animals (Mustela lutreola, Tarsiger cyanurus) can also be expected from the east.

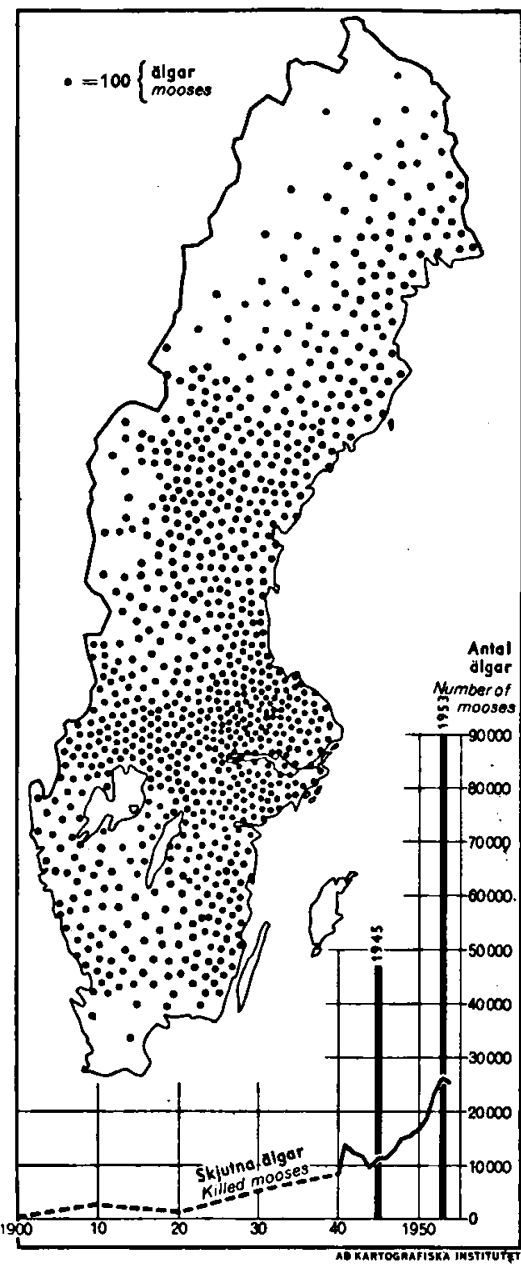

3. Distribution of the elk or moose (Alces alces) in Sweden 1953. The estimated number of moose in 1953 was about 90.000 animals. Formerly the moose was dispersed over all forest bearing parts of Sweden, but at the beginning of the 19th century the species had decreased and was limited to a rather small area in Sweden, where the population of today is most dense. Through total protection in 1808-1817 and 1826-1835 respectively, the moose was saved from extinction and began to spread again. During the past hundred years the species has continually increased. The staple diagrams reflect the number of elks obtained at two censuses in 1945 and 1953. The curve shows the harvest, that in 1959 was 32.286 animals. After K. Curry-LiN. DAHL 1957.

Perhaps the most remarkable events during the present century are the enormous increase of the elk, the unparallelled expansion of the roe northwards, and the re-appearance of the lynx as a resident of 


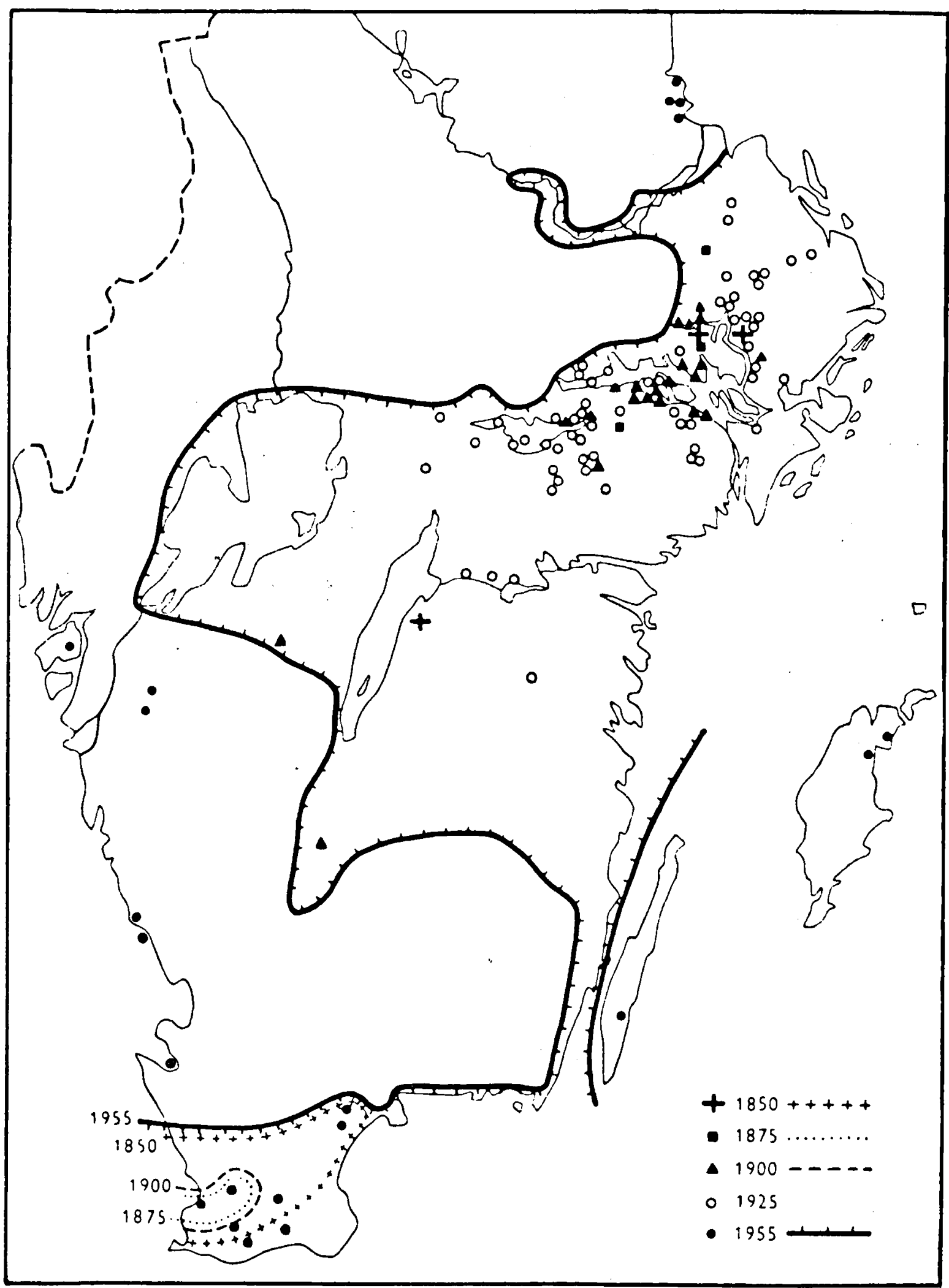

4. Distribution changes of the mute swan (Cygnus olor) in Sweden from 1850 tot 1955. After K. CurRY-LndahL 1958 B. 
Smalland and some other southern provinces. There are many birds of different species (Streptopelia decaocto, Phylloscopus trochiloides, Muscicapa parva, Serinus canaria, Carpodacus erythrinus) on their way northwards to new ranges. A number of them are quite recent additions to the Swedish avian fauna, and almost every year birds new to Sweden arrive to Scandinavia. Not infrequently these strangers are pioneers of a coming expansion which at first may be slow, tentative as it were, until at last, some favourable spring with suitable climatic conditions, it suddenly explodes and rapidly occupies a number of bridgeheads.

Among the birds that have spread rapidly during the present century are the starling (Sturnus vulgaris), the fieldfare (Turdus pilaris), the marsh harrier (Circus aeruginosus), the osprey (Pandion haliaëtus), the her-

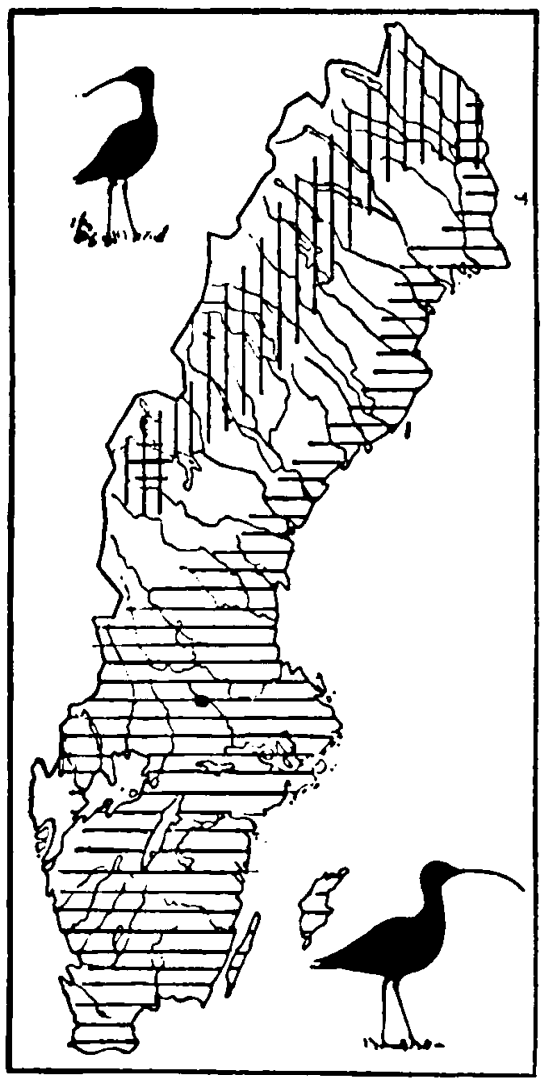

5. Distribution ranges in Sweden of the whimbrel (Numenius phaeopus) (in the northwest) and of the curlew (N.arquata) are only overlapping in central and northwestern Sweden, but the latter species is expanding following the cultivated valleys in the northern part of the country. After K. Curry-Lindahl 1955.

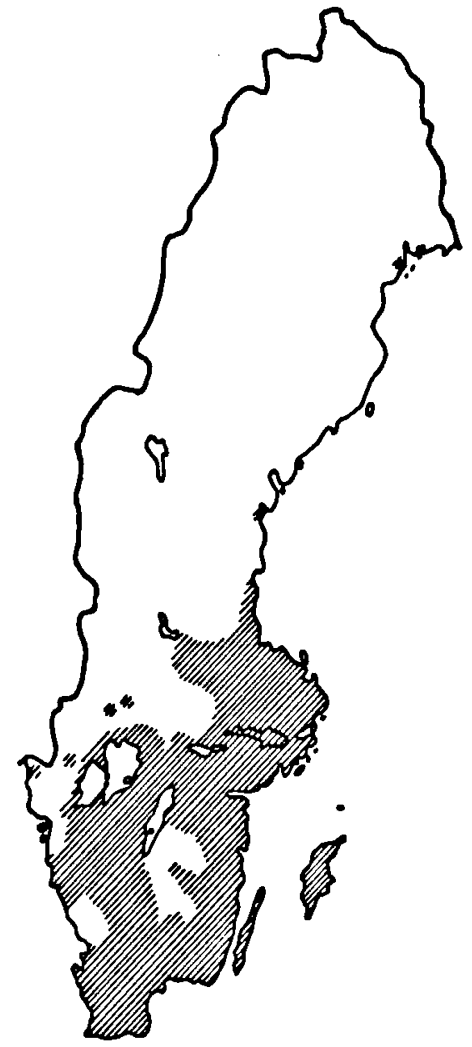

6. The distribution of the coot (Fulica atra) in Sweden corresponds to the occurrence of eutrophic lakes. After K. CurryLINDAFL $1960 \mathrm{~B}$.

on (Ardea cinerea), the mute swan (Cygnus olor), the tufted duck (Aythya fuligula), the great-crested grebe (Podiceps cristatus), the Slavonian grebe (P. auritus), the wood pigeon (Columba palumbus), the common curlew (Numenius arquata), the black-headed gull (Larus ridibundus), the herring gull (L.argentatus), the water rail (Rallus aquaticus), the moorhen (Gallinula chloropus) and the coot (Fulica cristata). It will be noticed that many of the birds on their way northwards are water birds typical of lakes rich in nutriment. It is possible that this expansion can be explained by the progressive drying up of lakes and marshes in the southeastern steppe regions, at the same time as the temperature in northern Europe has risen. These climatic fluctuations are probably a repetition of similar earlier phenomena. We are no doubt concerned with long, rhythmical, secular cycles which affect birds most noticeably in the animal world.

Reptiles and amphibians, in spite of a rising mean temperature in the twentieth century, seem to be retreating somewhat. These creatures belong to groups that are mainly adapted to life in warmer latitudes. 
The occurrence of certain species in northern Europe must be viewed against the background of the warm, post-glacial period, when they immigrated and reached their present ranges. Since then, with the exception of a few species, they seem to have been retreating steadily southwards.

Shoals of tunas are becoming more and more common in Swedish waters off the west coast, as are those of other fishes with a southern distribution.

During the first half of the twentieth century the population of Sweden increased by nearly two million people. In 1950 there were twice as many people in the country as there had been a century earlier. But seventy years ago there were a million more people living in rural areas than there are now. Further, enormous technical developments, which have transformed both the countryside and the way of life, have taken place during the same space of time. This process has in its turn also caused an increase in the numbers of several species of animals that have been able to adapt themselves to, and have been favoured by, the new conditions. The fox (Vulpes vulpes), the hooded crow (Corvus corone), the blackbird (Turdus merula) and the herring gull are a few of these species. Others have been less adaptable, but a surprisingly large number of animal species seem able to live side by side with man in presentday Sweden-if they were only allowed to do so. It is most often man who prevents such co-existence.

The present distribution of animals is, as implied above, due largely to historical reasons, but it is not only changes in the habitat that causes alterations in the distribution in one or another direction. The adaptability of the species, its power to compete, its dynamics, that is to say the characteristics of the species, are also of great importance. The continually changing ecological conditions favour some species, but handicap others. An example of this in our days is the increasing frequency of the elk, the roe, and several birds. On the other hand we have the retreat of the wolf and the decline of the crested lark (Galerida cristata), the white stork (Ciconia ciconia) and the fire-bellied toad (Bombina bombina).

The role of man in nature is of great significance as an ecological and zoogeographic factor. Man has, more than any other species, either directly or indirectly, consciously or unconsciously, transformed great areas of his surroundings in a very short time. In Sweden this transformation has covered practically the whole of the country; only parts of the mountain ranges and the seas have hitherto remained unchanged.



7. Distribution of Sweden's three species of snakes, showing the northern limits of ranges. - Coronella austriaca (= hasselsnok) is a southern element, which probably invaded Sweden from the south via Denmark, from where only eight records are known; the last was made in 1914. Except in the Aland archipelago it does not occur in Finland. - Natrix natrix $(=$ snok) is thermally intermediate between the smooth snake and the adder, which is also shown by its distribution area. - Vipera berus (= huggorm) is less sensitive to cold and occurs in northern areas as well as in birch forest region. This species may have arrived from the south as well as from the east, which is not excluded for the ringed snake either. After K. Cunry-Lindahl 1958 A.

It is not only by extensive changes of habitats in the form of cultivation, draining, changes of water level for hydro-electric developments and the like 


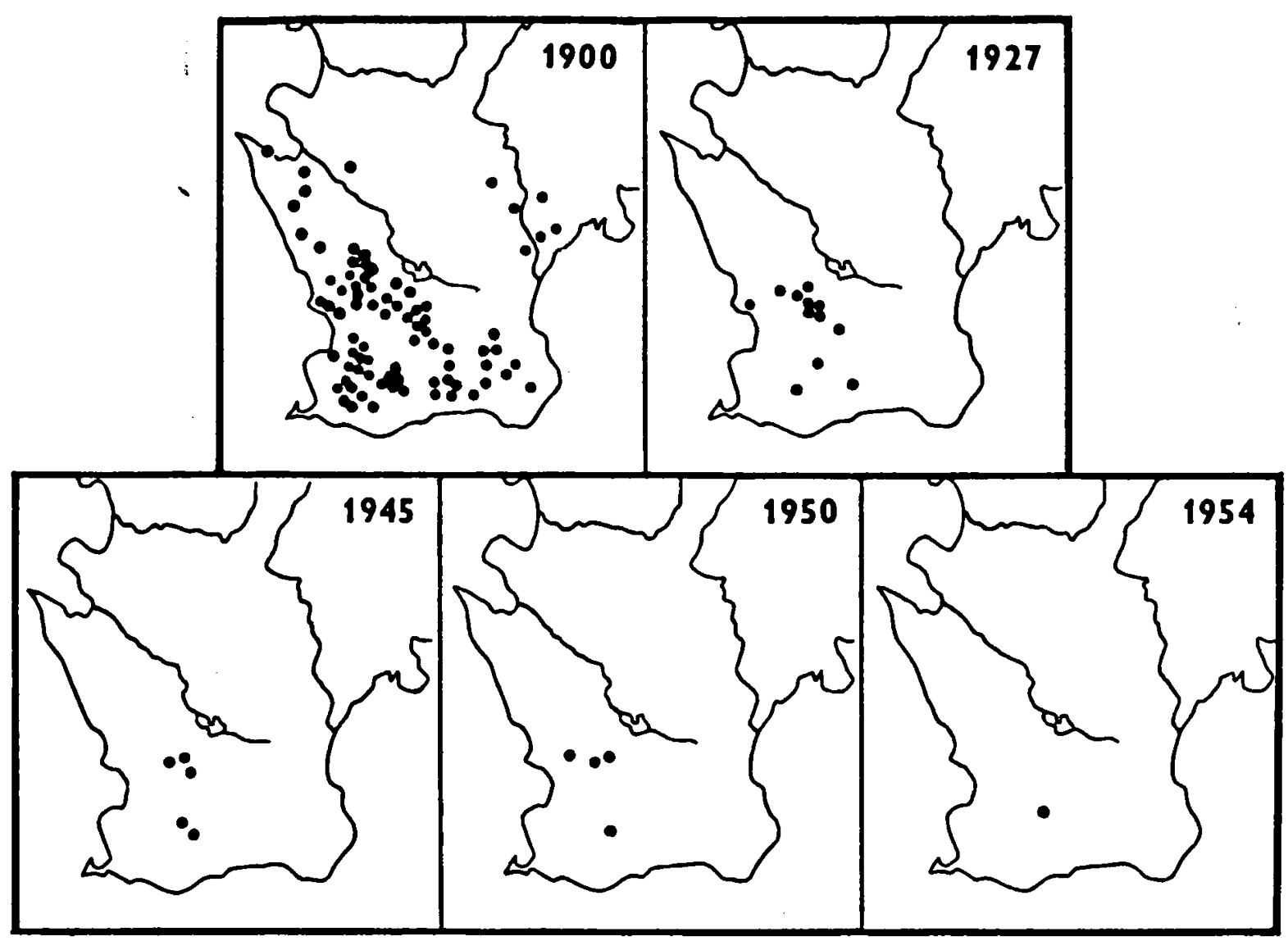

8. The decrease of the white stork (Ciconia ciconia) in Sweden in 1900-1954. Dots indicate breeding pairs. The two nestlings of the only Swedish nest in 1954 died halfgrown. No breeding in 1955 and later. After K. CurRy-LindahL 1957.

that man has altered the possibilities of existence for animals. He also interferes directly in the size of the populations by hunting, one-sided and continuous subduction of predators, oil pollution in the seas, which at one blow may exterminate whole populations of wintering aquatic birds, the introduction of foreign species, the use of insecticides and the like. All these start an almost endless chain reaction in the habitats affected, and the consequences may be unexpected and unfortunate. Many examples could be given.

In the course of the thousands of years that have elapsed since the last glaciation, the climate has fluctuated in mighty, many-thousand-year cycles. During historic times it has been possible to register the minor fluctuations in Sweden. The twelfth, thirteenth and fourteenth centuries seem to have been relatively mild; the period 1400 to 1700 , on the other hand, considerably colder. At present the temperature shows a rising trend. During the past hundred years, however, the temperature curve has been rather erratic. Small fluctuations have occurred in a largely warmer climate. Thus the period between about 1860 and 1920 had a maritime trend with mild winters and cool summers. After that the climate became more continental with cold winters and warm summers, but now the tendency again seems to be in the direction of a maritime climate. These small variations seem to have caused considerable changes in the animal world, particularly among such mobile species as birds, sea-fishes and winged insects. A new advance towards the north has been observed among southerly species, while northerly species are moving in the same direction, but this tendency is not general. More and more birds winter in their breeding quarters, and for other species the winter quarters extend farther north.

Changes in climate far from Scandinavia may cause an immigration into north Europe of birds compelled to seek new habitats for reproduction because of an increasing aridity in their original range. 
A landscape is dependent on climate, and it may therefore be said that faunal changes due to climatic factors are also caused by changes in the habitat. In an analysis of the variations in the frequency of animal species, therefore, the changes of the landscape due to man, or to causes originating directly from the actions of man, must be distinguished from those caused by climatic ecological factors in which man has played no part.

In the following discussion, consideration has been paid only to those vertebrate species which, during a long period of observation, have shown either a clear increase or decrease, not only in frequency, but above all in geographical distribution. In this connection animals deliberately introduced by man are ignored completely, as are changes that took place in prehistoric times.

During recent centuries, ninety-one species of Swedish vertebrates have shown significant fluctuations in frequency. Of these forty-five have increased, while the other forty-six have decreased (Tables I and II). Birds are in the majority in both groups, with thirty-five species increasing and thirty decreasing. The equivalent figures for mammals are five and thirteen.

TABlE I. Variations in distribution and frequency Symbols

$+=$ Increase

$-\quad=$ Decrease

Abbreviations for causes

$\mathrm{Cl}=$ Climatic factors

$\mathrm{E}=$ Ecological factors except man and climate

$\mathbf{H a}=$ Human activities

\section{Abbreviations for habitats}

$\mathrm{A}=$ Arctic and subarctic regions

$C=$ Coasts

$\mathrm{F}=$ Forests

Hs = Human settlements

$\mathrm{Ma}=$ Marshes

$\mathbf{M}=$ Mountains

$\mathbf{P}=$ Plains

$\mathbf{S}=$ Sea

$\mathrm{U}=$ Ubiquitous species

$\mathrm{W}=$ Watercourses (lakes, rivers)

Abbreviations for categories

$\mathrm{Mi}=$ Migratory

$\mathrm{N}=$ Nomadic

St $=$ Stationary

Species

Lepus timidus Castor fiber

Rattus rattus

R. norvegicus

$\begin{array}{cccc} & \text { Cause } & \text { Habitat } & \text { Category } \\ - & \text { Ha } & \text { F } & \text { St } \\ - & \text { Ha } & \text { W } & \text { St } \\ - & \text { E } & \text { Hs } & \text { St } \\ + & \text { E } & \text { Hs } & \text { St }\end{array}$

Species

Canis lupus

Vulpes vulpes

Alopex lagopus

Ursus arctos

Meles meles

Gulo gulo

Lynx lynx

Phoca vitulina

$P$. hispida

Halichoerus grypus

Capreolus capreolus

Cervus elaphus

Alces alces

Rangifer tarandus

Podiceps cristatus

$P$. griseigena

$P$. auritus

Ardea cinerea

Ciconia ciconia

Aythya fuligula

A. ferina

Clangula hyemalis

Somateria mollissima

Tadorna tadorna

Anser anser

A. erythropus

A. fabalis

Branta bernicla

Cygnus olor

C. cygnus

Aquila chrysaëtos

Accipiter gentilis

Milvus milvus

Haliaeetus albicilla

Circus aeruginosus

Pandion haliaëtus

Falco peregrinus

$F$. rusticolus

Lyrurus tetrix

Tetrao urogallus

Rallus aquaticus

Crex crex

Gallinula chloropus

Fulica atra

Otis tarda

Haematopus ostralegus

Vanellus vanellus

Charadrius dubius

Gallinago gallinago

G. media

Numenius arquata

Philomachus pugnax

Larus argentatus

L. ridibundus

Chlidonias nigra

Fratercula arctica

Columba oenas

C. palumbus

Streptopelia decaocto

Bubo bubo

Coracias garrulus

Galerida cristata

$\begin{array}{ccc} & \text { Cause } \\ - & \mathrm{Ha} \\ + & \mathrm{Ha} \\ - & \mathrm{Ha} \\ - & \mathrm{Ha} \\ + & \mathrm{E}+\mathrm{Cl} \\ - & \mathrm{Ha} \\ - & \mathrm{Ha} \\ - & \mathrm{Ha} \\ - & \mathrm{Ha} \\ - & \mathrm{Ha} \\ +\mathrm{Ha}+\mathrm{Cl}+\mathrm{E} \\ -\quad \mathrm{Ha} \\ + & \mathrm{Ha}+\mathrm{E} \\ - & \mathrm{Ha}\end{array}$

Habitat

$\mathbf{F}+\mathbf{A}$

Category

G

$\mathbf{A}$
$\mathbf{F}+\mathrm{A}$

F

$A+F$

F

C

C

C

F

F

A

$+\quad E$
$+\quad E$

$+\quad E$

$+\quad E$

- E

$+\quad E$

$+\mathbf{E}$

- E+Ha?

$+\mathrm{Ha}$

$+\quad$ E

- ?

- $\mathrm{Ha}$

$-\mathrm{Ha}+\mathrm{E}$ ?

- E

$+\mathrm{E}+\mathrm{Ha}$ ?

- $\mathrm{Ha}$

- Ha

- $\mathrm{Ha}$

- ?

- $\mathrm{Ha}$

$+\mathrm{Ha} ?+\mathrm{E}$

$+\mathrm{E}+\mathrm{Ha}$ ?

- $\mathrm{Ha}$

- $\mathrm{Ha}$

- E+Ha?

- E+Ha?

$+\mathrm{E}+\mathrm{Cl}$

- $\mathrm{Ha}$

$+\mathrm{E}+\mathrm{Cl}$

$+\mathrm{E}+\mathrm{Cl}$

$-\mathrm{Ha}+\mathrm{E}$ ?

$+\quad \mathrm{E}$

$+\quad \mathrm{E}$

$+\mathrm{Ha}$

- $\mathrm{Ha}$

- ?

$+\quad \mathrm{E}$

- $\mathrm{Ha}$

$+\mathrm{Ha}+\mathrm{E}+\mathrm{Cl}$

$+\quad \mathbf{E}$

- ?

- ?

- $\mathrm{Ha}$ ?

$+\quad \mathrm{E}$

$+\quad E$

- $\mathrm{Ha}$

- $\mathrm{Cl}$

- E

$\begin{array}{cc}\text { W } & \text { Mi } \\ \text { W } & \text { Mi } \\ \text { W } & \text { Mi } \\ \text { W } & \text { Mi } \\ \mathrm{Hs}+\mathbf{P}+\mathrm{W} & \mathrm{Mi} \\ \text { W } & \mathrm{Mi} \\ \text { W } & \mathrm{Mi} \\ \text { W } & \mathrm{Mi} \\ \mathbf{C} & \mathrm{Mi} \\ \mathbf{C} & \mathrm{Mi} \\ \mathrm{C}+\mathrm{W} & \mathrm{Mi}\end{array}$

$\mathrm{F}+\mathrm{Ma} \quad \mathrm{Mi}$

C $\mathrm{Mi}$

W St

$\begin{array}{cc}\text { F+A } & \text { St }+ \text { Mi }\end{array}$

F N

$\mathrm{F}+\mathrm{W} \quad \mathrm{Mi}$

$\mathrm{W}+\mathrm{C} \quad \mathrm{St}+\mathrm{Mi}$

W Mi

W Mi

M $\quad \mathrm{Mi}$

A $\mathrm{St}+\mathrm{Mi}$

$\mathrm{F}+\mathrm{Ma} \quad \mathrm{St}$

F St

W $\mathrm{Mi}$

P $\quad$ Mi

W $\quad \mathrm{Mi}+\mathrm{St}$

W $\quad \mathbf{S t}+\mathbf{M i}$

P $\mathbf{M i}+\mathrm{St}$

$\mathrm{C}+\mathrm{W} \quad \mathrm{Mi}$

$\mathbf{W}+\mathbf{P} \quad \mathbf{M i}$

$\mathrm{C}+\mathrm{W}+\mathrm{Hs} \quad \mathrm{Mi}$

$\mathbf{W}+\mathbf{A} \quad$ Mi

W+A $\quad$ Mi

W+P $\quad$ Mi

$\mathbf{W}+\mathbf{A} \quad \mathbf{M i}$

$\mathrm{C}+\mathrm{W} \quad \mathrm{Mi}+\mathrm{N}+\mathrm{St}$

$\mathrm{W}+\mathrm{C} \quad \mathrm{Mi}+\mathrm{St}$

W $\mathrm{Mi}$

C $\mathrm{Mi}$

$\mathrm{F}+\mathrm{C} \quad \mathrm{Mi}$

$\mathrm{F}+\mathrm{P}+\mathrm{Hs} \quad \mathrm{Mi}+\mathrm{St}$

$P \quad S t$

$\mathbf{F}+\mathbf{C}+\mathbf{A} \quad \mathbf{S t}$

F Mi

$\mathrm{Hs}+\mathbf{P} \quad \mathrm{St}$
A $\mathrm{Mi}$ 


\begin{tabular}{|c|c|c|c|c|}
\hline \multicolumn{2}{|l|}{ es } & Cause & Habitat & Category \\
\hline Corvus corax & - & $\mathrm{Ha}$ & $\mathbf{F}+\mathbf{C}$ & $\begin{array}{c}\mathrm{St} \\
\mathrm{Mi}+\mathrm{St}\end{array}$ \\
\hline C. $c o$ & $\begin{array}{l}t \\
t\end{array}$ & $\begin{array}{l}\mathrm{Ha} \\
\mathrm{F}\end{array}$ & $\begin{array}{c}\mathbf{G} \\
\mathbf{P}+\mathbf{F} \perp \mathbf{H s}\end{array}$ & $\mathbf{M i}+\mathbf{S t}$ \\
\hline C. monedula & + & E & $\mathbf{P}+\mathbf{F}+\mathbf{H s}$ & St \\
\hline Garrulus glandarius & + & E & $\mathbf{F}$ & St \\
\hline Turdus pilaris & + & $\mathbf{E}$ & $\mathbf{F}+\mathbf{A}$ & $\mathbf{N}+\mathbf{M i}$ \\
\hline T. musicus & + & $\mathbf{E}$ & $\mathbf{A}+\mathbf{F}$ & $\mathbf{M}$ \\
\hline$T$. merula & + & $\mathbf{E}$ & $\mathbf{F}+\mathbf{H s}$ & $\mathbf{M i}+\mathbf{S t}$ \\
\hline Phoenicurus ochruros & + & $\mathbf{E}$ & Hs & Mi \\
\hline ia luscinia & + & $\mathrm{E}+\mathrm{Cl}$ ? & $\mathrm{F}+\mathrm{Hs}$ & Mi \\
\hline ella naevia & + & $\mathbf{E}$ & W & Mi \\
\hline halus scirpaceus & + & $\mathbf{E}$ & $\mathbf{W}$ & Mi \\
\hline Sylv & + & $\mathbf{E}$ & G & Mi \\
\hline Prunella modularis & + & $\mathbf{E}$ & $\mathbf{F}+\mathbf{A}$ & Mi \\
\hline Anthus campestris & 一 & $\mathbf{E}$ & $\mathbf{C}+\mathbf{P}$ & Mi \\
\hline Sturnus vulgaris & + & E+Ha? & G & Mi \\
\hline Carduelis carduelis & - & $?$ & $\mathbf{F}+\mathbf{P}$ & $\mathbf{N}+\mathbf{M i}$ \\
\hline Emberiza & 一 & E & $\mathbf{P}$ & \\
\hline na bombina & - & $?$ & $\mathbf{P}$ & St \\
\hline Sal & & $\mathrm{H}$ & W & \\
\hline S. trutta & - & $\mathbf{H}$ & W & Mi \\
\hline Lucioperca sandra & + & $\mathbf{E}$ & $\mathbf{W}+\mathbf{C}$ & $\mathbf{S t}+\mathbf{N}$ \\
\hline Mullus surmuletus & + & $\mathbf{E}$ & $\mathbf{S}$ & St \\
\hline Thunnus thynnus & + & E & $\mathbf{S}$ & Mi \\
\hline Scopthalmus $n$ & + & $\mathbf{E}$ & $\mathbf{S}$ & Mi \\
\hline Pleuronectes platessa & + & $\mathrm{E}$ & $\mathbf{S}$ & $\mathbf{M i}+\mathbf{S t}$ \\
\hline
\end{tabular}

An analysis of the reasons for the increase or decrease in the different species (Table III) shows that, as a result of changes in the landscape caused by man, or other factors directly traceable to man, seven species (three mammals and four birds) have been favoured, while no fewer than twenty-six species (twelve mammals, twelve birds, and two fishes) have found their habitats and ranges greatly reduced; one species has been exterminated (the wild reindeer) and another has been re-introduced after extermination (the beaver, Castor fiber).

The consequences of other ecological factors, chiefly climatic, have been quite different, for they have favoured no fewer than thirty-four species (two mammals, twenty-seven birds, and five fishes), while only eight species, (one mammal, and seven birds) have declined in frequency, and their geographical distribution has become restricted.

TABLE II. Variations in distribution and frequency

\begin{tabular}{|c|c|c|}
\hline & Increase & Decrease \\
\hline $\begin{array}{l}\text { Mammals } \\
\text { Birds } \\
\text { Reptiles } \\
\text { Batrachians } \\
\text { Fishes }\end{array}$ & $\begin{array}{r}5 \text { species } \\
35 \text { species } \\
- \text { species } \\
- \text { species } \\
5 \text { species }\end{array}$ & $\begin{array}{r}13 \text { species } \\
30 \text { species } \\
- \text { species } \\
1 \text { species } \\
2 \text { species }\end{array}$ \\
\hline Total & 45 species & 46 species \\
\hline
\end{tabular}

TABLE III. Probable causes of increase or decrease

\begin{tabular}{|ll|c|c|}
\hline & & $\begin{array}{c}\text { Changes in land- } \\
\text { scape due to man } \\
\text { or man's direct } \\
\text { actions }\end{array}$ & $\begin{array}{c}\text { Climatic and } \\
\text { other ecological } \\
\text { changes (except } \\
\text { man's rôle) }\end{array}$ \\
\hline Mammals increase & 3 & 2 \\
Birds & $\begin{array}{c}\text { decrease } \\
\text { increase } \\
\text { Fishes }\end{array}$ & 12 & 1 \\
& $\begin{array}{c}\text { decrease } \\
\text { increase } \\
\text { decrease }\end{array}$ & 12 & 27 \\
\hline Total & increase & 2 & 7 \\
& decrease & 7 & 5 \\
\hline
\end{tabular}

There are several species of different vertebrates of which it is at present impossible to say whether human or other factors are responsible for the changes now going on or already completed. One of these is the great bustard, now extinct in Sweden.

Table IV shows how the number of species within the different classes of animals have shared the increase or decrease in various habitats, and whether they are resident, migratory or nomadic. Many species of animals belong to more than one of the biotopes mentioned, e.g. the wood pigeon, which is found in woods, in the groves on the plains, round human settlements, and now even in towns. This bird is increasing in all these habitats. Other animals, e.g. the pike-perch (Lucioperca sandra), are advancing chiefly in only one of the habitats, the coast, and are thus represented in the table only under that type of the environment.

Only three habitats have an increased number of species, viz. SEA, WATERCourSEs, and areas, covered by ubiquitous species, which include habitats found all over the country.

The distinction between the human and other ecological factors causing changes in the fauna is an artificial one, not only on account of the fact that man himself is a biological creature included in the processes of nature in the same way as animals, but also because he, in many ways, affects directly the size of animal populations. When man, with misguided zeal, reduces the number of predators, for example, he may cause positive or negative consequences for other species. If a predator is exterminated or greatly reduced in numbers in one district, it may for a time favour other species, but the next step is frequently competition for food between the individuals of the species that humans wished to help, or another predator is given an opportunity to increase unhindered (e.g. the fox after the elimination of 


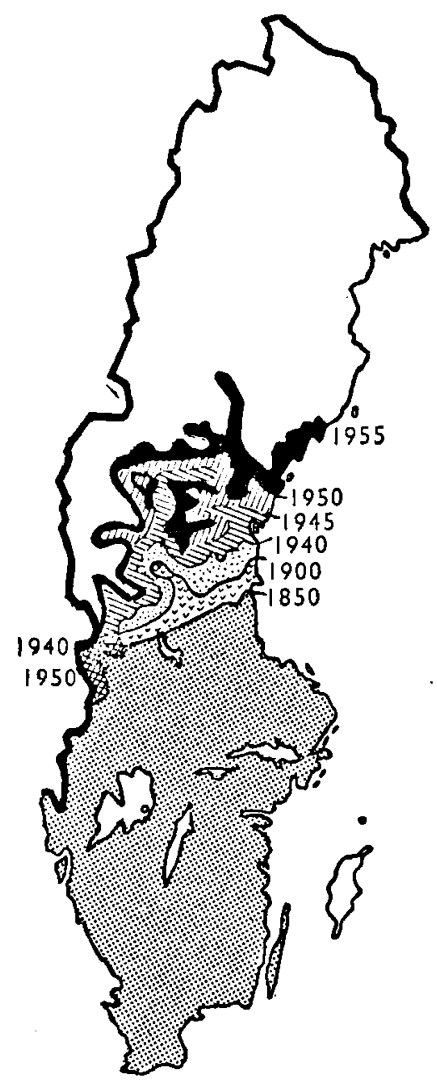

9. Extension of range of the badger (Meles meles) in Sweden from 1850 to 1955 . After K. CurRYLINDAHL 1960 A.

the wolf and the lynx). Thus practically every interference by man that changes the character of a biocoenosis begins a chain reaction of inverted habitat conditions for animals and plants. An extremely good example of this is what happened in Europe after the extermination of the rabbit by myxomatosis.

Let us study in greater detail the thirty-three species of vertebrates whose way of life has been changed by the activities of man. We will begin with those that have been unfavourably affected.

The mountain hare (Lepus timidus) was driven from the southern plains of Sweden by the brown hare, introduced by man, and it is now rare south of the northern boundary of Scania.

Formerly the beaver was to be found by many of the watercourses of Sweden, probably all over the country. It was exterminated by man, the last known specimen being shot in Jämtland in 1871. In 1922 the first beavers were reintroduced into the same province. They were followed by others, and now
Sweden has a reliable population of beavers. In some places, however, the beaver has again been reduced as a consequence of water regulation, against which all the constructional skill and industry of the fourfooted engineers are in vain, particularly as shortperiod regulation, for hydro-electric purposes, usually takes place during the winter, when the dams made by the beavers to protect their dwellings are damaged and their stores of food washed away.

Rather more than 100 years ago the wolf was to be found all over Sweden. During the period 1827$1839,6,790$ wolves were killed in Sweden, eighty-two of them in Scania and 271 around Stockholm. As late as 1883 there were wolves in Uppland, north of the Swedish capital. In 1945 a State census showed that the number of wolves in the country did not exceed twenty-five, a low figure, but, however, probably much too optimistic in view of the wolf's low reproduction figures. The wolf is now Sweden's most uncommon carnivore, and is obviously of the verge

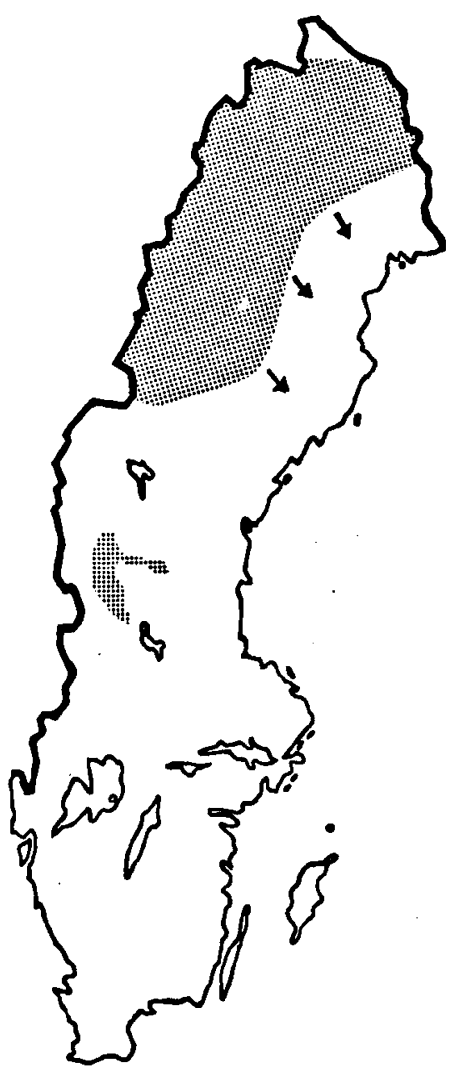

10. Distribution of the brown bear (Ursus arctos) in Sweden. Arrows indicate dispersal trends during the last years. After K. Curry-LnNDAHL $1960 \mathrm{~A}$. 
TABLE IV. Resident, migratory and nomadic species of increasing or decreasing vertebrates, distributed according to habitat

\begin{tabular}{|c|c|c|c|c|c|c|c|c|c|c|c|c|c|}
\hline & 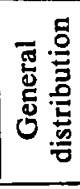 & 宽莺 & 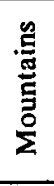 & 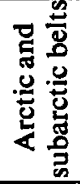 & జే & 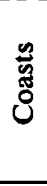 & $\begin{array}{l}\text { : } \\
\text { : }\end{array}$ & 总 & $\frac{\underline{\omega}}{\frac{\omega}{\alpha}}$ & 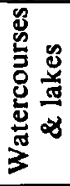 & 空 & 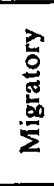 & 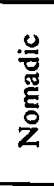 \\
\hline $\begin{array}{c}\text { Mammals } \\
\text { increase } \\
\text { decrease }\end{array}$ & 1 & $\begin{array}{l}1 \\
1\end{array}$ & & $\begin{array}{l}0 \\
4\end{array}$ & & $\begin{array}{l}0 \\
3\end{array}$ & & $\begin{array}{l}3 \\
6\end{array}$ & $\begin{array}{l}1 \\
0\end{array}$ & $\begin{array}{l}0 \\
1\end{array}$ & $\begin{array}{l}5 \\
9\end{array}$ & $\begin{array}{l}0 \\
1\end{array}$ & $\begin{array}{l}0 \\
3\end{array}$ \\
\hline $\begin{array}{l}\text { Birds } \\
\text { increase } \\
\text { decrease }\end{array}$ & $\frac{2}{-}$ & $\begin{array}{l}2 \\
2\end{array}$ & $\begin{array}{l}0 \\
1\end{array}$ & $\begin{array}{l}3 \\
4\end{array}$ & & $\begin{array}{l}5 \\
6\end{array}$ & $\begin{array}{l}0 \\
3\end{array}$ & $\begin{array}{r}8 \\
11\end{array}$ & $\begin{array}{l}4 \\
7\end{array}$ & $\begin{array}{l}19 \\
10\end{array}$ & $\begin{array}{r}10 \\
6\end{array}$ & $\begin{array}{l}31 \\
24\end{array}$ & $\begin{array}{l}2 \\
1\end{array}$ \\
\hline $\begin{array}{c}\text { Batrachians } \\
\text { increase } \\
\text { decrease }\end{array}$ & & & & & & & & & $\begin{array}{l}0 \\
1\end{array}$ & & $\begin{array}{l}0 \\
1\end{array}$ & & \\
\hline $\begin{array}{l}\text { Fishes } \\
\text { increase } \\
\text { decrease }\end{array}$ & & & & & 0 & $\begin{array}{l}1 \\
0\end{array}$ & & & & $\begin{array}{l}0 \\
2\end{array}$ & $\begin{array}{l}1 \\
0\end{array}$ & $\begin{array}{l}3 \\
2\end{array}$ & \\
\hline $\begin{array}{l}\text { Total } \\
\text { increase } \\
\text { decrease }\end{array}$ & 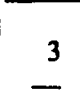 & $\begin{array}{l}3 \\
3\end{array}$ & $\begin{array}{l}0 \\
1\end{array}$ & $\begin{array}{l}3 \\
8\end{array}$ & $\begin{array}{l}4 \\
0\end{array}$ & $\begin{array}{l}6 \\
9\end{array}$ & $\begin{array}{l}0 \\
3\end{array}$ & $\begin{array}{l}11 \\
17\end{array}$ & $\begin{array}{l}5 \\
8\end{array}$ & $\begin{array}{l}19 \\
13\end{array}$ & $\begin{array}{l}15 \\
16\end{array}$ & $\begin{array}{l}34 \\
27\end{array}$ & $\begin{array}{l}2 \\
4\end{array}$ \\
\hline
\end{tabular}

of extinction. If it were not for a continuous immigration from the east, it would no longer be a member of the Swedish fauna.

Thus the wolf is a species that, owing to direct persecution by man, has had to retreat to the most inaccessible parts of the country.

The arctic fox was formerly to be found everywhere in the mountain range. Shooting and poisoning were most probably the main causes of the reduction of the species. In spite of a long period of protection it has been unable to regain its former frequency.

During the past three centuries bears have been compelled to withdraw from the greater part of their former Swedish range. They were reduced in numbers and the survivors were driven to the mountains. In 1925 the bear was protected on Crown lands. This period of protection lasted till 1942 , and seems to have led to a stabilization of the population in the mountain areas, in the valley af the Vindel, for example, and parts of the Lule Lappmark, where the populations were good. In 1942 hunting was permitted for two months annually, and in some mountain districts the bears were reduced greatly in number. At the end of the 1940s and during the 1950s bears have wandered down from the mountains to the coniferous forests, and thus returned to places from which they had been absent for half a century. This movement is not caused by a pressure of overpopulation in the mountains.

During this movement the bear has penetrated as near the coast as the Niemisel and Boden districts, which shows, among other things, that it is not the cultivation of the countryside but direct persecution by man that has restricted the geographical distribution of the bear in Sweden. Nowadays the Sarek National Park, where hunting is prohibited (except for Lapps), with the surrounding forest land, is the best bear country in Sweden.

Despite bitter persecution, the wolverine (glutton) has succeeded remarkably well in keeping its former distribution area in the mountains, although a considerable reduction has occurred in the forest land. In this case, too, it is direct persecution by man that has been decisive. The wolverine is in fact primarily a mountain species, although it occurs in the forests too.

The lynx, too, has suffered form persecution by man. It is a forest dweller, and its reduction has been rapid in Sweden since the species was hunted down mercilessly during the nineteenth century. In the decade 


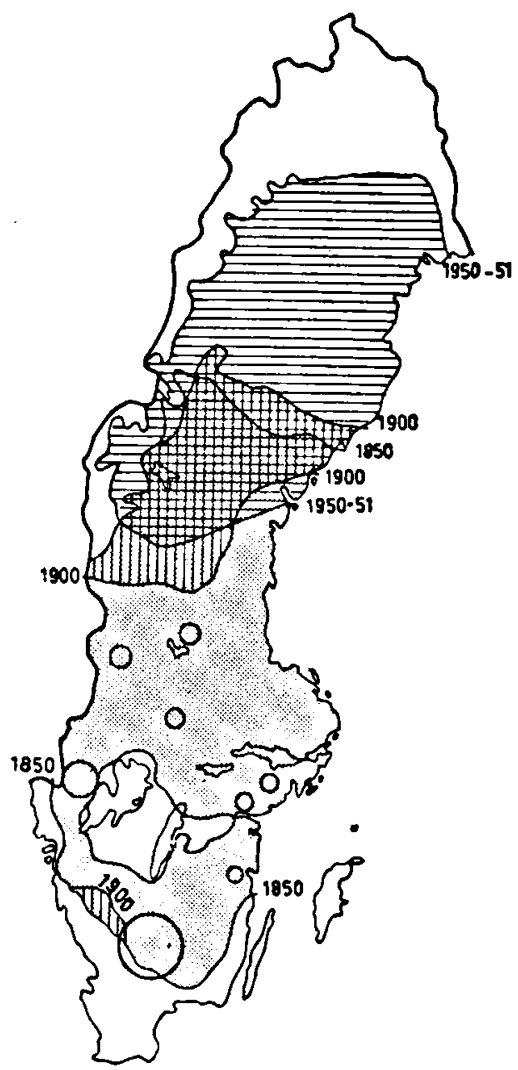

11. Regression of distribution of the lynx (Lynx lynx) in Sweden from 1850 to 1900 and increase from 1925 to 1951 . Circles = concentration of records during 19401954. After K. Curry-LindahL $1958 \mathrm{~A}$.

1827 to $1836,2.506$ lynxes were shot in the country, but from 1916 to 1925 only 117 .

During the first half of the nineteenth century the lynx occurred as far south as Småland and Blekinge, while its limit in the north ran through northern Jämtland and Angermanland. Only isolated nomadic animals visited southern Lapland and Västerbotten. This distribution is interesting, for it shows that until the hunting of the lynx with modern, devastating weapons began, the main habitat of the species was southern and central Sweden. Nowadays the main geographical distribution of the lynx is in the north; the area that formerly marked the northern limit of the animal is now only slightly north of the southern limit of its continuous range. As early as 1850 , however, there was a gap in its habitat formed by the plains of Västergötland and Östergötland.

About the year 1900 the lynx had retreated from the whole of the southern and central parts of Sweden except for the northernmost parts of Dalarna and the wooded districts of south-western Västergötland on the borders of Halland, where it disappeared about 1906. At the same time the northern limit had moved northwards, but not far enough to compensate the animal for its lost territory in the south. In 1925 the permanent distribution area was at a minimum, and was almost wholly in Jämtland. In 1928 the lynx was protected in the whole of Sweden. There were then possibly a few left in Jämtland, but as Einar LöNNBERG wrote in 1930, they must have been very few. The same writer stated at the same time that the lynx had been practically exterminated in Västerbottens län.

Unless these reports give a too low estimate of the frequency of the lynx in Norrland in 1925, the protection of the species came in the nick of time. During fifteen years of immunity from hunters, the lynx increased slowly, and the limits of its range were moved northwards and eastwards. No movement southwards, which would have been more natural for this species, seems to have occurred, however. But unexpected finds of lynx were made in Dalsland during the 1920s and 1930s. It is uncertain whether these isolated occurrences were recruited from the few lynxes in Norway, or whether the lynx has never really been exterminated in Dalsland.

In 1943 lynx-hunting was allowed for two months in Sweden. At about the same time finds of lynx were reported from along a passage through Uppland, Södermanland, Östergötland and Småland, and in south-western Sweden it was met with in southern Dalsland, Västergötland and western Småland, where it is still resident.

In spite of the fact that the lynx has increased its distribution area in Sweden, and thereby demonstrated that it can live side by side with man and his domestic animals, the species is still on the verge of extermination, due solely to persecution, though locally the population of Jämtland is at present at a rather satisfactory level.

On the basis of the bounty paid for shooting seals, the three species resident in Sweden-the common seal (Phoca vitulina), the ringed seal ( $P$. hispida) and the grey seal (Halichoerus grypus)-are clearly declining in numbers. The cause of this can hardly be other than man who, by disturbing them at their breeding places and persecuting them in the archipelagoes and coast districts, reduces the populations. The maritime landscape is changed as man takes possession of islets and rocks from the seals. The fact that the ringed 


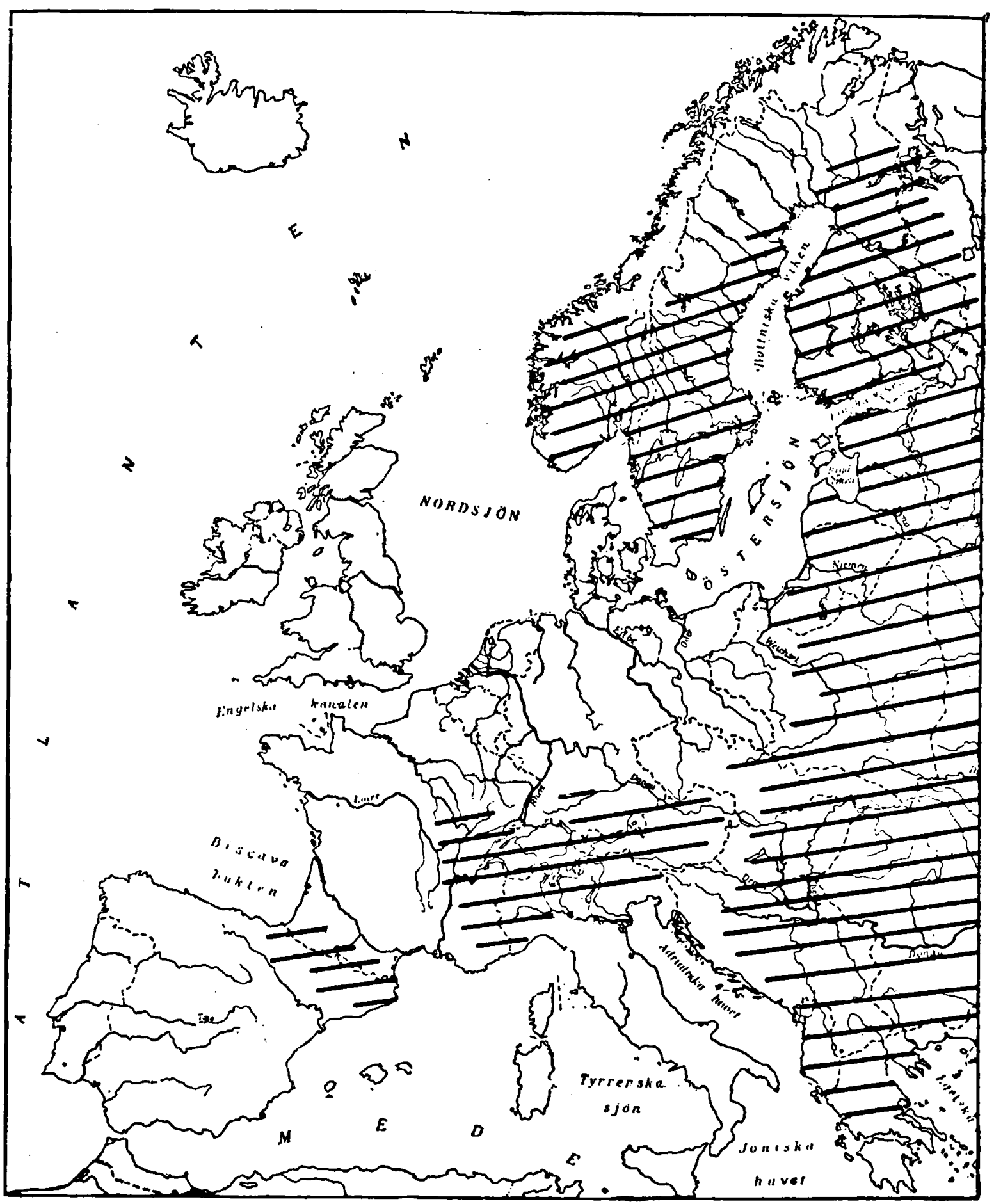

12. Distribution of the lynx (Lynx lynx) in Europe about 1800. After K. Curry-LindarL 1951.

seal was able to survive the long warm period in the Baltic indicates that, in spite of its Arctic origin, it is not for reasons of climate that it is retreating from the Baltic sea,
The red deer (Cervus elaphus), which was still to be found in Östergötland in the seventeenth and eighteenth centuries, is now restricted by man to Scania, where the population probably consists of 


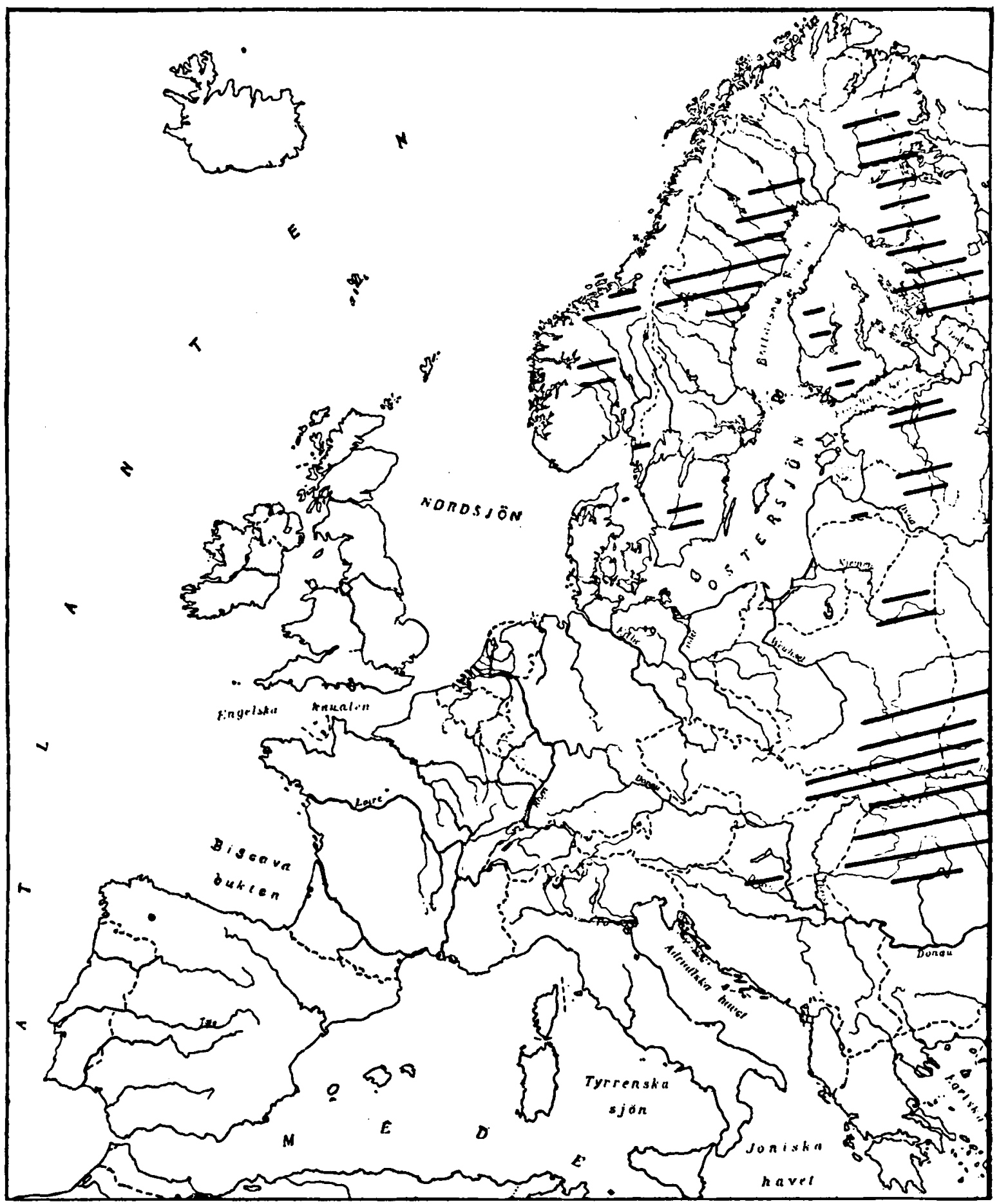

13. The distribution of range of the lynx $(\operatorname{Lynx} \operatorname{lynx})$ in Europe in 1950 shows quite another picture than 150 years earlier. After K. CurRY-LindahI. 1951.

about 150 animals. An attempt to introduce it into Västergötland has been successful, which shows that the species can be introduced into suitable forest tracts.
A few centuries ago wild reindeer were found in all the mountain districts of Sweden and in large parts of the Norrland forests, in Norrbotten right down to the coast. It was exterminated little by little by the 
Lapps, who shot the last specimens about 1880 . The wild reindeer still exists in Norway.

The reduction and local extermination of many birds have been the results of purposeful decimation or unconscious interference on the breeding sites. To this category of birds belong the lesser white-fronted goose (Anser erythrops), the whooper-swan (Cygnus cygnus), the golden eagle (Aquila chrysaëtos), the goshawk (Accipiter gentilis), the white-tailed sea eagle, the peregrine falcon (Falco peregrinus), the gyr-falcon ( $F$. rusticolus), the corncrake (Crex crex), the eagle owl and the raven (Corvus corax). It is typical that the majority of these species are birds of prey and owls. The lesser white-fronted goose has for years been the victim of ruthless slaughter in its hidden, isolated moulting localities during the period when it cannot fly. In 1940, for example, the skulls of 270 birds, all of which had obviously been killed at the same time, were found at Virihaure in Swedish Lapland. Such massacres set their mark on the frequency of the lesser white-fronted goose for a long time, for geese from great areas gather at the moulting places.

Another group of birds has been driven from its dwelling places by drainage and similar actions. Several of these species have found similar habitats in southern and central Sweden in exchange, for marshes are born, live, and die in rapid succession in a post-glacial, young country with land elevation, such as Sweden. Some species, however, have decreased visibly both numerically and as regards distribution. Among these are the snipe (Gallinago gallinago), and, above all, the ruff (Philomachus pugnax), both of which are now mainly to be found in Norrland.

The catastrophic decrease in the frequency of salmon (Salmo salar) and trout (S. trutta) in Swedish waters is due solely to man.

Unlike those mentioned above, there are other animals that have clearly been favoured by man and his transformation of the landscape. Directly encouraged by the general cultivation of the land and by man's extermination of predators are the fox and the hooded crow, two species that know how, in the absence of enemies, to make the best of practically all types of habitat and everything edible that human beings leave behind them. The advance of the roe and the elk is due, naturally, to a number of contributory factors, of which man is not the least important. At the end of the eighteenth century and the beginning of the nineteenth, the two species, curious though it may seem today, were on the verge of extinction. This critical situation was gradually followed by a spectacular expansion which is without parallel in northern Europe. Under the protection of the law, the elk re-occupied practically the whole of Sweden. and the roe is well on the way.

The little ringed plover (Charadrius dubius) is a wader, which in the inland has occupied different habitats created by man. Rubbish tips, the banks of artificial ponds, and bathing beaches have been colonized by this species. The herring gull is clearly favoured by rubbish tips, from which it is able to satisfy its demand for food. It is only during recent years that this new source of food has been utilized. It is probable that other ecological factors have contributed to the enormous increase of this species. The eider (Somateria mollissima) has increased greatly in numbers during recent years, which seems to be directly due to the protection the bird has enjoyed.

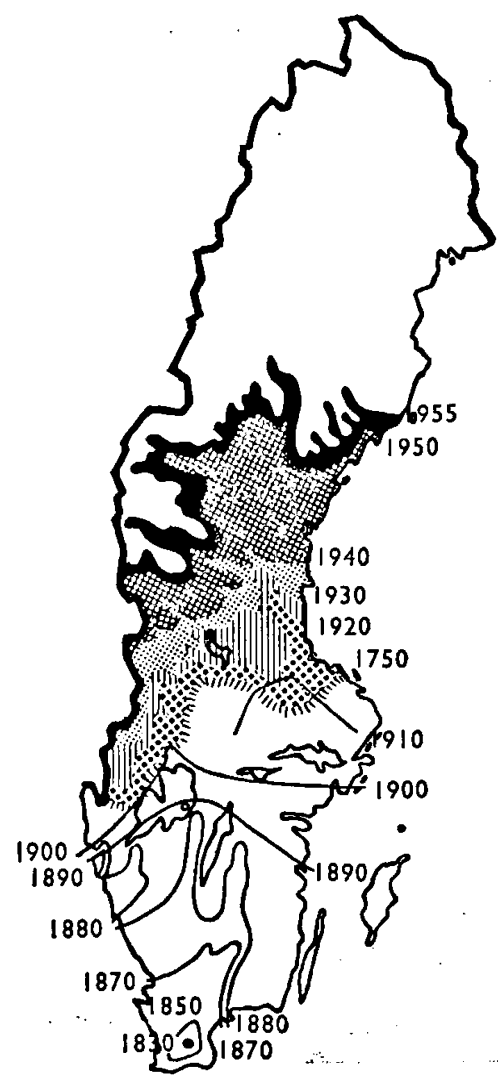

14. Retreat of the roe deer (Capreolus) from 1750 to 1830 was followed by a miraculous spread northwards over Sweden. The expansion was particularly rapid between 1940-1955. After K. CurRy-Lindahl 1958 A. 
It is difficult at present to determine how much the reduction or increase in number and range of many animals is due partly to man or wholly to other ecological factors. The Swedish populations of the longtailed duck (Clangula hyemalis), for example, have been declining rapidly. It is known that the species is often the victim of terrible oildischarge catastrophes in the Baltic sea, but it is not known whether they have affected particularly the inhabitants of Swedish mountain waters. The bean goose (Anser fabalis) has declined greatly in numbers both on its Swedish breeding grounds and in its European wintering places, where it is hunted, but in this case, too, it has been impossible to show any causal connection. If the reduction or disappearance of the greylag goose (A. anser) from its former nesting sites is due to hunting and interference is impossible to determine with certainty, but it seems not unlikely. The decimation of the black-grouse and caper-caillie in comparison to that of former centuries, depends probably in the first place on ecological factors caused by the transformation of forests and heaths into cultivated land, but in this case, too, other factors unconnected with man may be present. Human beings played an important rôle in the extermination of the great bustard, but it is possible that other factors also contributed. The decline of the stock dove (Columba oenas) is usually attributed to man, who has destroyed its nesting trees, but the species is so versatile in its choice of nesting places that this can hardly be the only cause. In any case, the stock dove does not by any means seem to be in uninterrupted retreat.

The increase in the numbers of the mute swan and the marsh harrier during the past quarter of a century coincides with their periods of protection, but at the same time a number of aquatic birds and waders that are not wholly protected show a similar expansion. Man was formerly the only vertebrate enemy of the mute swan, and its protection, therefore, has probably contributed greatly to the augmentation of its geographical distribution and its increased frequency.

The osprey, which is not dependent on eutrophic lakes for its fishing, and which was also protected much later than the mute swan and the marsh harrier, is another species that has increased greatly, particularly during the past fifteen to twenty years. Its preservation may be a contribution to this tendency, but it can hardly be the principal cause. Nearly alone of all the birds of prey, the osprey is able to draw on the great number of lakes and coastal waters for its food, and its nesting places are not necessarily in the vicinity of its fishing domains, but are quite often at some distance from them.

The starling is helped by cultivation, but its exzansion northwards has probably another background, although it has been facilitated by human activities. Olavi Kalela (1950) assumes that the starling formerly had a northern limit which for reasons of climate moved southwards during the seventeenth and eighteenth centuries, and that its present expansion is a re-occupation of its old habitat.

Many animals are hampered greatly by man, but it is doubtful whether the species in question are decreasing in numbers. The hedgehog (Erinaceus europaeus), for example, is more than any other animal the victim of the motorcar. During motoring trips in southern and central Sweden, large numbers of dead hedgehogs, which have been run over during the night, can be seen on the roads. This new factor must, in the long run, influence the frequency of the species.

It is getting more and more difficult for bats to find suitable accommodation in trees and buildings. The golden plover (Charadrius apricarius) is being driven from many marshes in southern Sweden, but the mountain population remains intact.

The reader probably expected to find in Table I other birds that vary in frequency. Such birds as the bittern, the black-tailed godwit (Limosa limosa), the avocet (Recurvirostra avocetta), the razorbill (Alca torda), the wren (Troglodytes troglodytes) and the redstart (Phoenicurus phoenicurus) (increasing in Norrland) show changes in frequency during such a short period as the first half of the present century, probably on account of climatic factors such as severe or mild winters (the bittern, the razorbill, the wren), or favourable climatic circumstances during the spring migration with consequent colonization (the bittern, the black-tailed godwit, the avocet, the redstart). These variations, therefore, have nothing to do with the transformation of the landscape. Short-term fluctuations do not give sufficient evidence for a longterm forecast.

It is impossible in this paper to discuss all the species which, in Table I, are assumed to increase on account of ecological, mainly climatic factors.

Sweden is a sparsely populated country in comparison with other European countries, and this is, and always has been, a positive factor in the possibilities of animals to survive in spite of a steady transformation of the countryside. Hardest pressed are the large carnivores, which are feared by man, and of which man's opinions are prejudiced.

Several species of animals possess a remarkable 
ability to adapt themselves to continually changing conditions. To this must be added that the number of species seems to be on the increase by immigration. Sweden's situation on the periphery of the geographical distribution of many animals implies that changes in a northerly direction often result in new additions to the Swedish fauna. It may therefore be assumed, rather paradoxically, that the number of species of vertebrates in Sweden will increase rather than decrease, in spite of the fact that man is busily engaged in reducing the habitats of the animals. Just at present the tendency is in that direction, as a biological consequence of the improved climate. But the climatic pendulum may swing in the opposite direction, and then the fauna will abandon the northern countries first.

\section{REFERENCES}

Kalela, O., 1950: Zur säkularen Rhytmik der Arealveränderungen europäischer Vögel und Säugetiere, mit besonderer Berücksichtigung der Uberwinterungsverhältnisse als Kausalfaktor. Ornis Fennica, XXVII: pp. 1-30.

LLoyd, L., 1831: Field Sports of the North of Europe comprised in a personal narrative of a residence in Sweden and Norway in the years 1827-1828. 2nd ed. 760 pp. London.

LöNNBERG, E., 1930: Lodjurets förekomst i Sverige de sista hundra åren. Kungl. Svenska Vetenskapsakademiens Skrifter i Naturskyddsärenden. 14: pp. 1-36.

The maps are reproduced from the following literature: Curry-Lindahl, K., 1950: Berguvens, Bubo bubo (L.), förekomst i Sverige jämte något om dess biologi. Vår Fågelvärld. 9: pp. 113-165.
Cukny-LindahL, K., 1951: Lons (Lynx lynx) historia och nuvarande förekomst i Sverige och övriga Europa. Sveriges Natur, yearbook. 42: pp. 122-162.

Curry-Lindahl, K., 1955: Diuren och människan i svensk natur. 463 pp. Stockholm.

Curky-Lindahl, K., 1957: Några djurarters utbredning. Atlas över Sverige. 45-46: pp. 1-8.

Curny-Lundahl, K., 1958: A. Djurgeografi, populationsdynamik och nutida faunaförändringar. Ymer. 78: pp. 5-57.

Curry-Lindahu, K., 1958: B. Svanarna på Stockholms ström. Sveriges Natur, yearbook. 49: pp. 111-119.

Curry-Lindahl, K., 1960: A. Diuren i färg - däggdjur, kräldjur, groddjur. 2nd ed. 199 pp. Stockholm.

Curry-Lindahl, K., 1960: B. Våra Fåglar i Norden. Part II, 2nd ed., pp. 559-1022. Stockholm. 